\title{
Septoria tritici Blotch Development as Affected by Temperature, Duration of Leaf Wetness, Inoculum Concentration, and Host
}

\author{
C. Chungu, 104-111 Research Drive, Saskatoon, Saskatchewan, S7N 3R2, Canada; J. Gilbert and F. Townley- \\ Smith, Cereal Research Centre, Agriculture and Agri-Food Canada, 195 Dafoe Road, Winnipeg, Manitoba R3T \\ 2M9
}

\begin{abstract}
Chungu, C., Gilbert, J., and Townley-Smith, F. 2001. Septoria tritici blotch development as affected by temperature, duration of leaf wetness, inoculum concentration, and host. Plant Dis. $85: 430-435$

The effects of incubation temperature, leaf-wetness duration, inoculum concentration, and interaction between leaf-wetness duration and inoculum concentration on the development of Septoria tritici blotch were evaluated at the seedling stage in two bread wheats (Katepwa and 6 Lacos-78) and two durum wheats (AC Melita and Kyle). The study was conducted to assess if bread and durum cultivars widely grown in Manitoba and a resistant cultivar from South America react differently to the disease at temperatures characteristic of Manitoba summers, and to obtain information on conditions that would be used in differentiating resistant and susceptible cultivars under controlled conditions. The experiments were carried out under three temperature regimes. Factors that evaluated included inoculum concentration and duration of leaf wetness. Increasing incubation temperature, duration of leaf wetness, and inoculum concentration resulted in an increase in disease severity. There were significant $(P<0.05)$ differences for duration of leaf wetness and inoculum concentration within each cultivar. Pycnidia were observed 4 days earlier when incubation temperature increased from $18^{\circ} \mathrm{C}$ day $/ 15^{\circ} \mathrm{C}$ night to $22^{\circ} \mathrm{C}$ day $/ 15^{\circ} \mathrm{C}$ night or when inoculum concentration increased from $1 \times 10^{6} \mathrm{spores} / \mathrm{ml}$ to $1 \times 10^{7} \mathrm{spores} / \mathrm{ml}$. There were more pycnidia when duration of leaf wetness was $72 \mathrm{~h}$ as opposed to $48 \mathrm{~h}$ and $60 \mathrm{~h}$. The cultivar that was presumed to be resistant maintained its resistance under environmental conditions that are characteristic of Manitoba summers. We found that the optimal conditions for screening spring wheats for Septoria tritici blotch reaction were incubation temperatures of $18^{\circ} \mathrm{C}$ day $/ 15^{\circ} \mathrm{C}$ night, and $22^{\circ} \mathrm{C}$ day $/ 15^{\circ} \mathrm{C}$ night. Leaf wetness duration of 48 or $72 \mathrm{~h}$ and inoculum concentration of $1 \times 10^{7}$ spores $/ \mathrm{ml}$ consistently produced a susceptible reaction on Katepwa, AC Melita, and Kyle the three cultivars that were susceptible to Septoria tritici blotch.
\end{abstract}

Additional keywords: Mycosphaerella graminicola, resistance, speckled leaf blotch

Mycosphaerella graminicola (Fückel) Schroeter (Anamorph: Septoria tritici Rob. ex Desm.) is the causal pathogen of Septoria tritici blotch on bread wheat (Triticum aestivum L.) and durum wheat (T. turgidum [L.] subsp. durum). Septoria tritici blotch, also known as speckled leaf blotch, is characterized by necrotic blotches that contain black or dark brown pycnidia. The disease reduces yield and quality in many regions of the world $(3,4,19)$.

In Canada, little information is available on factors affecting disease severity and yield losses. Potts (12) studied physiologic specialization in a controlled environment by inoculating nine cultivars with nine $S$. tritici isolates from Saskatchewan, England, and Indiana. Results showed that

Corresponding author: C. Chungu

E-mail: cchungu@dowagro.com

CRC Contribution no. 1744.

Accepted for publication 22 December 2000.

Publication no. D-2001-0207-02R

(C) 2001 The American Phytopathological Society there was isolate specificity between isolates from Saskatchewan and those from Indiana and England. Potts (12) also assessed the components of resistance, including latent period, infection frequency, spore production and rate of lesion expansion on seedling and adult plants under controlled conditions. Cultivar Lacos had the longest latent period, lowest infection frequency, fewest pycnidia, and the lowest rate of lesion expansion.

Chungu et al. (2) evaluated yield losses of eight bread and durum cultivars grown in Canada by inoculating them with isolates from both bread wheat and durum. Yield losses ranged from 1.1 to $17.8 \%$ and 2 to $8 \%$ when cultivars were inoculated with a bread wheat isolate and a durum isolate, respectively. Katepwa, a cultivar with severe infection, suffered relatively small yield loss compared to cultivars with lower disease levels.

Septoria tritici blotch has been reported worldwide, but is most severe in wheat production areas that have cool, wet growing seasons $(4,9,20)$. In the past few years, prevalence and severity of Septoria tritici blotch has become more severe in western Canada, particularly in Manitoba (5) where summer daytime temperatures average between $22^{\circ} \mathrm{C}$ and $25^{\circ} \mathrm{C}$. Higher disease severity may be attributed to the above-average rainfall the province experienced in recent summers (Environmental Canada, Atmospheric Environment Service, 1992-1996). Our observations and data indicate that cultivars currently recommended for the Canadian prairies have little or no resistance to Septoria tritici blotch. To minimize yield loss, developing cultivars resistant to Septoria tritici blotch is an important goal.

It is difficult to obtain uniform epidemic conditions from year to year in wheat breeding field experimental plots. Moreover, evaluation of disease in artificially inoculated field nurseries is expensive and time consuming, especially if many lines must be assessed. Screening lines under controlled environments may allow elimination of those lines that are susceptible. Lines that appear to be resistant can be evaluated further in the field.

Genetic resistance to Septoria tritici blotch can be expressed as a reduction in lesion size or percentage of leaf surface area covered by pycnidia $(4,12,18,22)$. Nevertheless, consistent pycnidial production, even on susceptible bread wheat cultivars inoculated with $S$. tritici, requires optimal environmental conditions (22). Although the association between environmental conditions and development of Septoria tritici blotch $(7,13,16)$ is recognized, there is little information on the interaction of inoculum concentration, moisture, and temperature effects during the infection process.

Moisture is important at all stages of the disease cycle (15). Successful inoculation in the laboratory requires an extended incubation time in a moist chamber $(13,20)$. Temperature and leaf wetness period affect the rate of disease development and the severity of the disease (11). The effect of temperature, leaf wetness, and cultivar on the latent period of $S$. tritici on winter wheat was assessed by Shaw (16) who showed that latent period was temperature dependent. Increasing temperature from $5.2^{\circ} \mathrm{C}$ to $19.3^{\circ} \mathrm{C}$ decreased the latent period substantially. Varying leaf-wetness duration following initial infection, however, did not seem to have a significant effect on latent period in that study. Hess and Shaner (7) likewise reported a positive correlation 
between increase in post-inoculation moisture, post-infection temperature, and Septoria tritici blotch development.

Inoculum concentration plays an important role in the establishment and development of Septoria tritici blotch (18). An increase in inoculum density decreased the latent period in both susceptible and resistant cultivars by 1 to 2 days. In addition, higher inoculum concentration increased pycnidial formation by as much as $73 \%$ in susceptible cultivars and from 2 to $12 \%$ in resistant cultivars.

The cultivars widely grown in western Canada, are not resistant to Septoria tritici blotch and no information is available on the response of some of these cultivars to temperature, duration of leaf wetness, and inoculum load. A study was undertaken to determine if cultivars presumed to be resistant and which might be used as sources of resistance in a breeding program express resistance to Septoria tritici at temperatures representative of Manitoba summers, and to identify test conditions required to differentiate resistant from susceptible cultivars in greenhouse seedling tests.

\section{MATERIALS AND METHODS}

Fungal isolates. Two isolates of $S$. tritici were used: CRC 9801, an isolate from bread wheat collected near Boissevain, Manitoba, in 1996, and isolate 91014 collected from durum wheat in Ethiopia. Bread wheats were inoculated with CRC 9801 and durum wheats were inoculated with 91014.

Inoculum preparation. Pycnidiospores were isolated from wheat leaves previously inoculated with single-spore isolates of $S$. tritici. To avoid loss of pathogenicity, the fungus was re-isolated from infected leaves whenever inoculum was prepared. Pieces of infected leaf tissue, about $0.2 \mathrm{~cm}^{2}$ were surfaced-sterilized by immersing the samples in $0.5 \%$ sodium hypochlorite for 2 min, then rinsed twice in sterile water. The sterilized leaf tissues were plated on potato dextrose agar (PDA). Petri dishes were placed under continuous cool, white fluorescent light at ambient $\left(23\right.$ to $\left.25^{\circ} \mathrm{C}\right)$ temperature. After 2 days, pycnidiospores were picked up with a sterile wire loop, streaked on the surface of PDA plates, and incubated for 5 days. Inoculum was prepared by placing three $1-\mathrm{cm}^{2}$ pieces of agar culture plugs in a 500-ml erlenmeyer flask containing $250 \mathrm{ml}$ of yeast sucrose liquid medium (10.0 g sucrose, $10.0 \mathrm{~g}$ yeast extract in 1 liter distilled water). Flasks were placed on a wrist-action shaker for 5 days at room temperature.

Plant material. Two bread wheat cultivars (Katepwa and 6 Lacos-78) and two durum wheat cultivars (Kyle and AC Melita) were evaluated. Katepwa and 6 Lacos78 were selected based on their susceptibility and resistance, respectively, to $S$. tritici in preliminary studies. Kyle and AC Melita were selected based on seed avail- ability and good germination. Katepwa, Kyle and AC Melita are spring wheat cultivars commonly grown in western Canada and 6 Lacos-78 is a line from Uruguay. Ten seeds were sown in a $12-\mathrm{cm}$ diameter pot containing a mixture of four parts of soil and one part of Turface MVP (Profile Products LLC, Buffalo Grove, IL). An NP-K fertilizer (34-0-0) was applied immediately after sowing. Seedlings were later thinned to five per pot at the two-leaf growth stage (GS-12; 21).

Inoculation. Fourteen-day-old seedlings were inoculated at the four-leaf growth stage. Two drops of Tween 20 were added per $100 \mathrm{ml}$ of spore suspension. About 15 $\mathrm{ml}$ of spore suspension was applied per pot of five seedlings using a hand-operated sprayer. After inoculation, seedlings were placed in a mist chamber.

Seedling tests. Experiments to assess the effect of inoculum concentration and duration of leaf wetness were carried out. Based on results obtained from experiments assessing individual factors, we further evaluated the combined effects of inoculum levels of $1 \times 10^{6}$ and $1 \times 10^{7}$ spores $/ \mathrm{ml}$ and leaf wetness durations of 48 and $72 \mathrm{~h}$. All experiments were conducted in a split-split-plot design with four blocks except for the test assessing the duration of leaf wetness. Because results of a preliminary study that investigated the reaction of bread and durum wheat to different isolates showed that bread-wheat isolates were virulent only on bread wheat and vice
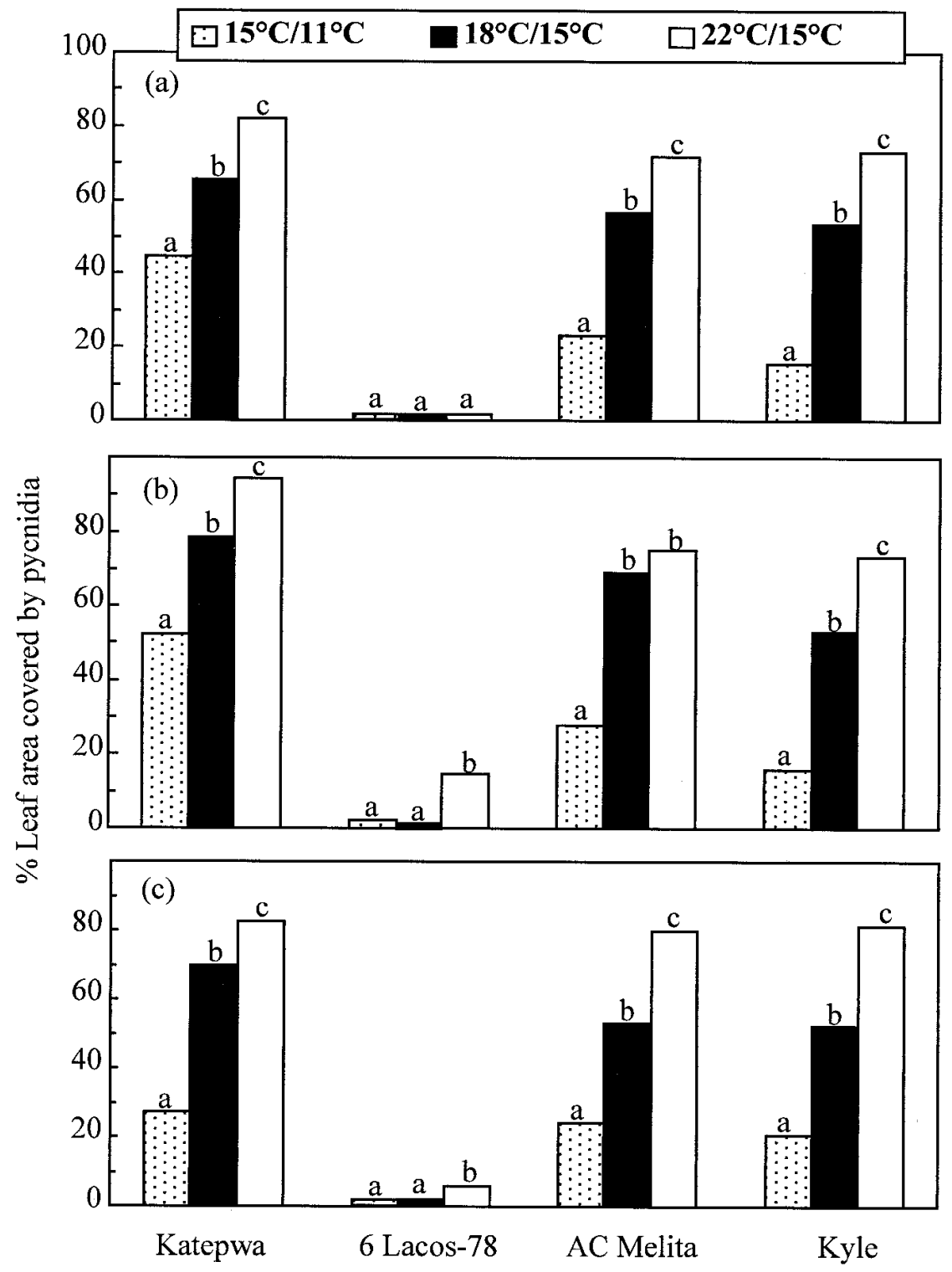

\section{Cultivars}

Fig. 1. Effect of incubation temperature on development of Septoria tritici blotch. Mean percent pycnidial coverage values were obtained from experiments assessing A, effect of four inoculum concentrations; $\mathbf{B}$, three durations of leaf wetness; and $\mathbf{C}$, combined effects of two inoculum concentrations and two durations of leaf wetness. Different letters associated with bars within genotypes are significantly different at $P<0.001$. 
versa, separate but parallel experiments were carried out for the bread and durum wheats. Incubation temperature was assigned to main-plots and cultivars were randomized to subplots in all tests. Subsubplots were: the four inoculum concentrations $\left(1 \times 10^{6}\right.$ spores $/ \mathrm{ml}, 2 \times 10^{6}$ spores/ $\mathrm{ml}, 1 \times 10^{7}$ spores $/ \mathrm{ml}$ and $2 \times 10^{7}$ spores/ $\mathrm{ml}$ ); three duration of leaf wetness periods $(48,60$, or $72 \mathrm{~h})$ and the four factorial treatment combination of inoculum concentration + duration of leaf wetness $(48 \mathrm{~h}$ $+1 \times 10^{6}$ spores $/ \mathrm{ml}, 48 \mathrm{~h}+1 \times 10^{7}$ spores/ $\mathrm{ml}, 72 \mathrm{~h}+1 \times 10^{6}$ spores $/ \mathrm{ml}$, and $72 \mathrm{~h}+1$ $\times 10^{7}$ spores $/ \mathrm{ml}$ ) to assess inoculum concentration, duration of leaf wetness, and combination of these two factors, respectively. All other treatment levels were compared to $48 \mathrm{~h}+1 \times 10^{6}$ spores $/ \mathrm{ml}$. After inoculation, plants were placed in the mist chamber and exposed to three leaf wetness periods $(48,60$, or $72 \mathrm{~h})$. During misting, plants were also supplied with diffused illumination with photon flux density of $10 \mu \mathrm{mol} / \mathrm{m}^{2} / \mathrm{s}$ for $8 \mathrm{~h}$. At the end of the misting period, the leaves were yellowish, so plants were immediately fertilized with a dilute solution of N-P-K fertilizer (20-20-20). All experiments were repeated once.

Incubation temperature. On removal from the mist chamber, plants were placed in growth cabinets and incubated at three temperature regimes $22^{\circ} \mathrm{C}$ and $15^{\circ} \mathrm{C} ; 18^{\circ} \mathrm{C}$ and $15^{\circ} \mathrm{C} ; 15^{\circ} \mathrm{C}$ and $11^{\circ} \mathrm{C}$ day and night, respectively. Plants were exposed to periods of 16-h day and 8-h night. The light was provided as a mixture of white fluorescent and incandescent illumination with photon flux density of $340 \mu \mathrm{mol} / \mathrm{m}^{2} / \mathrm{s}$. One week after inoculation, plants were observed daily for time of symptom devel-
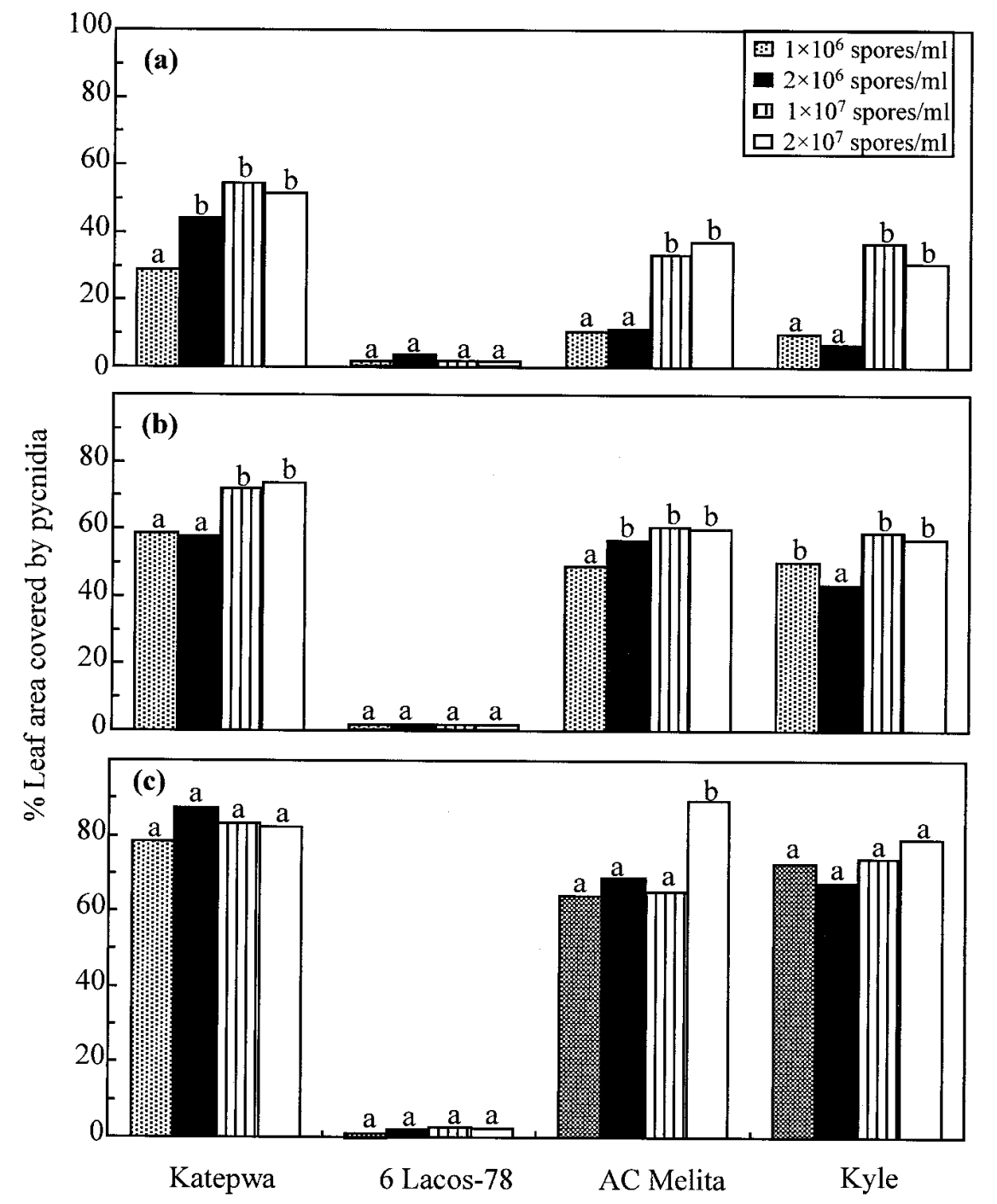

Cultivars

Fig. 2. Effect of inoculum concentration on reaction of seedlings of bread wheats, Katepwa and 6 Lacos-78, and durum wheats, AC Melita and Kyle, to Mycosphaerella graminicola at three postinoculation incubation temperatures: $\mathbf{A}, 15^{\circ} \mathrm{C}$ day $/ 11^{\circ} \mathrm{C}$ night; $\mathbf{B}, 18^{\circ} \mathrm{C}$ day $/ 15^{\circ} \mathrm{C}$ night; and $\mathbf{C}, 22^{\circ} \mathrm{C}$ day $/ 15^{\circ} \mathrm{C}$ night. Different letters associated with bars within genotypes are significantly different at $P$ $<0.001$.

opment. Plants were watered twice a week until they were rated.

Disease assessment. Disease severity was assessed 21 days after inoculation on the third and fourth leaf of every plant, using the Ziv-Eyal scale (4) for estimating percentage of pycnidial coverage on five plants. Pycnidial coverage was rated as the percentage of the total leaf surface area covered by pycnidia bearing necrotic lesions. Plants were classified as follows: resistant $=20 \%$ leaf area covered by pycnidia; moderately resistant $=21$ to $40 \%$; moderately susceptible $=41$ to $50 \%$, and susceptible $>51 \%$.

Data analysis. For each experiment, means of percent diseased leaf area were calculated from 20 plants in each treatment (five plants per block). Analysis of variance was used to assess significance of pycnidial coverage on cultivars and Duncan's Multiple Range Test used for separation of means. Homogeneity of error variances permitted pooling of data from repeated experiments.

\section{RESULTS}

Incubation temperature. Increase in incubation temperature accelerated the appearance of pycnidia. On Katepwa, Kyle, and AC Melita, pycnidia were observed 11 days after inoculation when incubation temperature was $22^{\circ} \mathrm{C}$ day $/ 15^{\circ} \mathrm{C}$ night, and 15 days after inoculation at incubation temperature of $18^{\circ} \mathrm{C}$ day $/ 15^{\circ} \mathrm{C}$ night. At an incubation temperature of $15^{\circ} \mathrm{C}$ day $/ 11^{\circ} \mathrm{C}$ night symptoms were observed 19 days after inoculation on the susceptible cultivars (AC Melita, Kyle, and Katepwa) and 21 days for 6 Lacos-78. Disease severity was significantly $(P<$ 0.001) different among the three incubation temperatures. The percentage of leaf area covered by pycnidia increased with the rise in incubation temperature from $15^{\circ} \mathrm{C}$ day/ $11^{\circ} \mathrm{C}$ night to $22^{\circ} \mathrm{C}$ day $/ 15^{\circ} \mathrm{C}$ night (Fig. 1). A slight increase in disease severity was also observed in the resistant genotype, 6 Lacos- 78 at $22^{\circ} \mathrm{C}$ day $/ 15^{\circ} \mathrm{C}$ night.

Inoculum concentration. The two bread wheats differed in severity at all inoculum concentrations $(P<0.001)$, but no differences were observed between the durum wheats. The interaction between cultivar and inoculum concentrations was also significant $(P<0.001)$ for both wheat types. An increase in inoculum concentration resulted in greater necrotic leaf area covered by pycnidia at the two higher temperatures than at the lowest temperature (Fig. 2). At $22^{\circ} \mathrm{C}$ day $/ 15^{\circ} \mathrm{C}$ night and $18^{\circ} \mathrm{C}$ day $/ 15^{\circ} \mathrm{C}$ night the effect of increasing inoculum concentration was less pronounced than at the $15^{\circ} \mathrm{C}$ day $/ 11^{\circ} \mathrm{C}$ night. However, this phenomenon was not observed in the resistant cultivar (Fig. 2).

Duration of leaf wetness. There were no significant effects on disease severity for cultivar and duration of leaf wetness for durum wheats (Fig. 3). Nevertheless, effect 
of cultivar, duration of leaf wetness, and the interaction between these factors were significant $(P<0.01)$ for bread wheats. Disease severity increased as duration of leaf wetness increased (Fig. 3). Katepwa consistently had higher disease severity than 6 Lacos-78 at all three leaf-wetness durations. Increasing incubation temperature to $22^{\circ} \mathrm{C}$ day $/ 15^{\circ} \mathrm{C}$ night resulted in an increase in percent area covered by pycnidia on 6 Lacos-78 at all three leafwetness durations. There was an increase in disease severity as duration of leaf wetness increased for AC Melita and Kyle.

Inoculum concentration and duration of leaf wetness. Cultivar effects and the combination of inoculum concentration and duration of leaf wetness were significant $(P<0.05)$ when plants were incubated at $15^{\circ} \mathrm{C}$ day $/ 11^{\circ} \mathrm{C}$ night for both wheat types. At other incubation temperatures, only cultivar effects were significant for the bread wheats. Increasing inoculum concentration from $1 \times 10^{6}$ to $1 \times 10^{7}$ spores/ml or using a concentration of $1 \times$ $10^{7}$ spores $/ \mathrm{ml}$ and a leaf-wetness duration of $72 \mathrm{~h}$ resulted in significant increases in disease severity (Fig. 4).

\section{DISCUSSION}

Changes in incubation temperature, inoculum concentration, and duration of leaf wetness affected symptom development in the four cultivars. Temperature was an important factor in determining the latent period. Percent pycnidial coverage increased as incubation temperature increased from $15^{\circ} \mathrm{C}$ day $/ 11^{\circ} \mathrm{C}$ night to $22^{\circ} \mathrm{C}$ day $/ 15^{\circ} \mathrm{C}$ night, similar to previous reports $(7,8,11,16)$. Latent period decreased as temperature increased in susceptible cultivars, but was not affected in the resistant cultivar. Similar findings have been reported by Shaw (16). Potts (12) found that a resistant cultivar had a longer latent period and fewer pycnidia. Although 6 Lacos-78 had a slight increase in disease severity at $22^{\circ} \mathrm{C}$ day $/ 15^{\circ} \mathrm{C}$ night, it still had high resistance to the pathogen. This cultivar restricts the development of pycnidia under field conditions (2). It appears that the two components of resistance, latent period and percent leaf area covered by pycnidia in 6 Lacos-78, could easily be exploited in a breeding program.

More pycnidia developed at $18^{\circ} \mathrm{C}$ day/ $15^{\circ} \mathrm{C}$ night and $22^{\circ} \mathrm{C}$ day $/ 15^{\circ} \mathrm{C}$ night than at $15^{\circ} \mathrm{C}$ day $/ 11^{\circ} \mathrm{C}$ night. We observed an increase in percent pycnidial coverage in bread wheats when duration of leaf wetness was longer than $48 \mathrm{~h}$. Magboul et al. (11) also found that temperatures between $20^{\circ} \mathrm{C}$ to $25^{\circ} \mathrm{C}$ favored infection when plants were exposed to leaf-wetness durations greater than $48 \mathrm{~h}$. In addition, we observed few or no pycndnia when duration of leaf wetness was disrupted for an hour or more during the misting period (data not reported), demonstrating the importance of having a continuous water film during incubation. Although microscopic studies were not performed in the present study, we speculate that disruption of misting may have dehydrated the hyphae so that few were able to penetrate the stomata.

Inoculum concentrations used in this study were 10 to 100 times higher than those of Shearer (18). Increasing inoculum levels resulted in higher disease severity in susceptible cultivars, in agreement with previous findings (18). Information on the number of conidia required to initiate infection in relation to the cultivar and environment is an important factor in assessing resistance to Septoria tritici blotch. In this study, inoculum concentration played a significant role in determining disease severity, especially at the lowest temperature. Increasing the inoculum concentration increased the number of spores that germi-
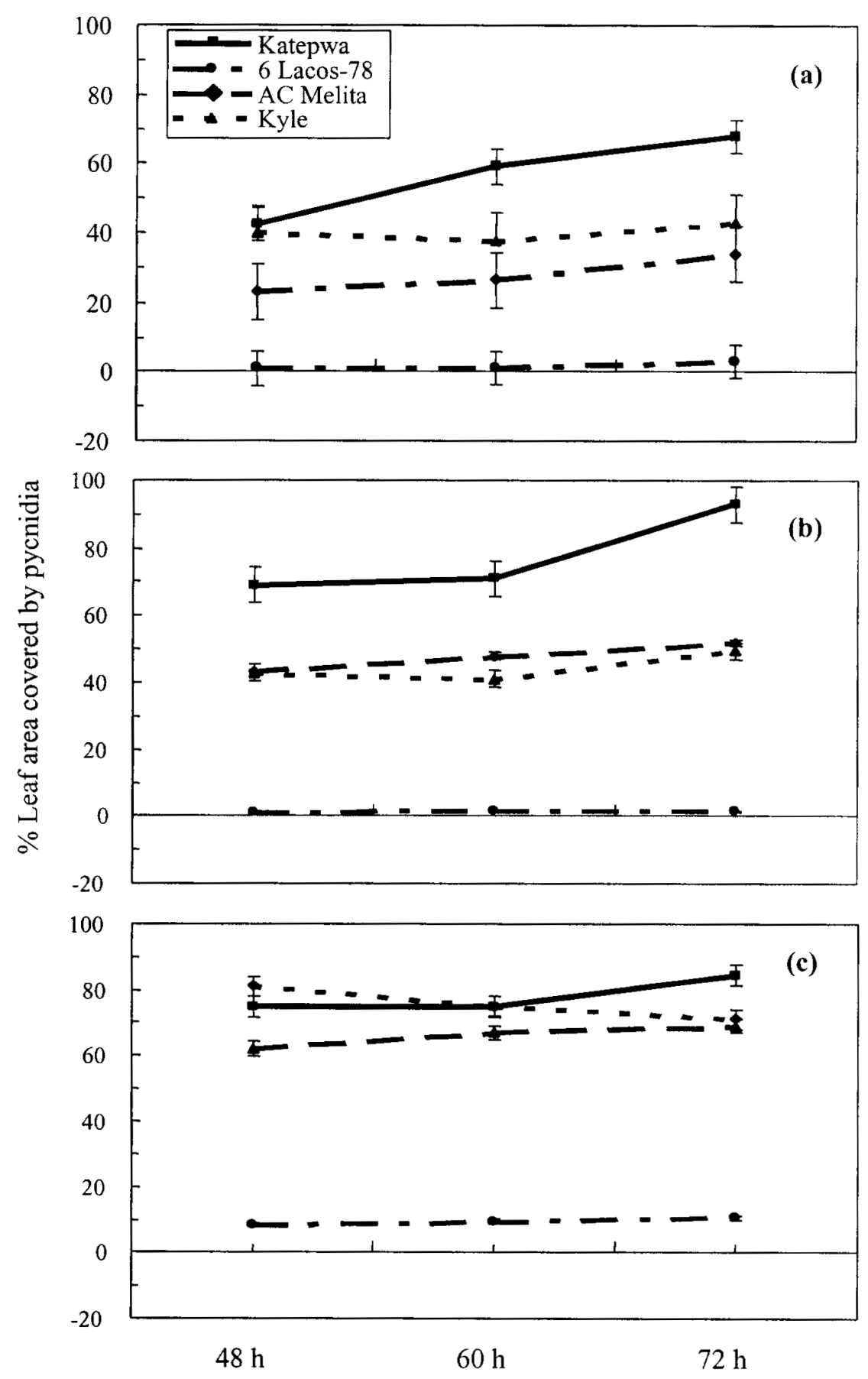

\section{Duration of Leaf Wetness (h)}

Fig. 3. Effect of duration of leaf wetness on Septoria tritici blotch development on seedlings of bread wheats, Katepwa and 6 Lacos-78, and durum wheats, AC Melita and Kyle, at three post-inoculation incubation temperatures: $\mathbf{A}, 15^{\circ} \mathrm{C}$ day $/ 11^{\circ} \mathrm{C}$ night; $\mathbf{B}, 18^{\circ} \mathrm{C}$ day $/ 15^{\circ} \mathrm{C}$ night; and $\mathbf{C}, 22^{\circ} \mathrm{C}$ day $/ 15^{\circ} \mathrm{C}$ night. Line graphs are only used to show the trend and do not imply that the duration of leaf wetness is a continuous variable. 
nated, and most likely the number of hyphae that penetrated the stomatal cavities. The effect of increasing inoculum concentration appears to have been more critical at $15^{\circ} \mathrm{C}$ day $/ 11^{\circ} \mathrm{C}$ night compared to $18^{\circ} \mathrm{C}$ day $/ 15^{\circ} \mathrm{C}$ night and $22^{\circ} \mathrm{C}$ day $/ 15^{\circ} \mathrm{C}$.

Various researchers $(6,8)$ have reported the importance of moisture or length of time in high relative humidity for conidia to successfully infect wheat. The observed increase in Septoria tritici blotch with an increase in duration of leaf wetness from 48 to $72 \mathrm{~h}$ is consistent with previous reports $(7,11)$. Increasing duration of leaf wetness resulted in a reduction in latent period by 2 to 4 days. The observed increase in disease symptoms at longer duration of leaf wetness may be associated with length of time the environment is conducive to germination of spores, germ tube growth, penetration, and colonization of host tissue (11). Shaner and Finney (14) and Hess and Shaner (8) similarly found that rainy days enhanced spore germination and subsequent infection.

Our results indicate that under favorable conditions of inoculum concentration and leaf-wetness duration, incubation temperature significantly influenced pycnidial development. Although disease development was not inhibited at $15^{\circ} \mathrm{C}$ day $/ 11^{\circ} \mathrm{C}$ night, it was relatively low compared to the $18^{\circ} \mathrm{C}$ day $/ 15^{\circ} \mathrm{C}$ night and $22^{\circ} \mathrm{C}$ day $/ 15^{\circ} \mathrm{C}$ night for all inoculum concentration and duration of leaf wetness combinations. The lowest concentration/duration of leaf wet-
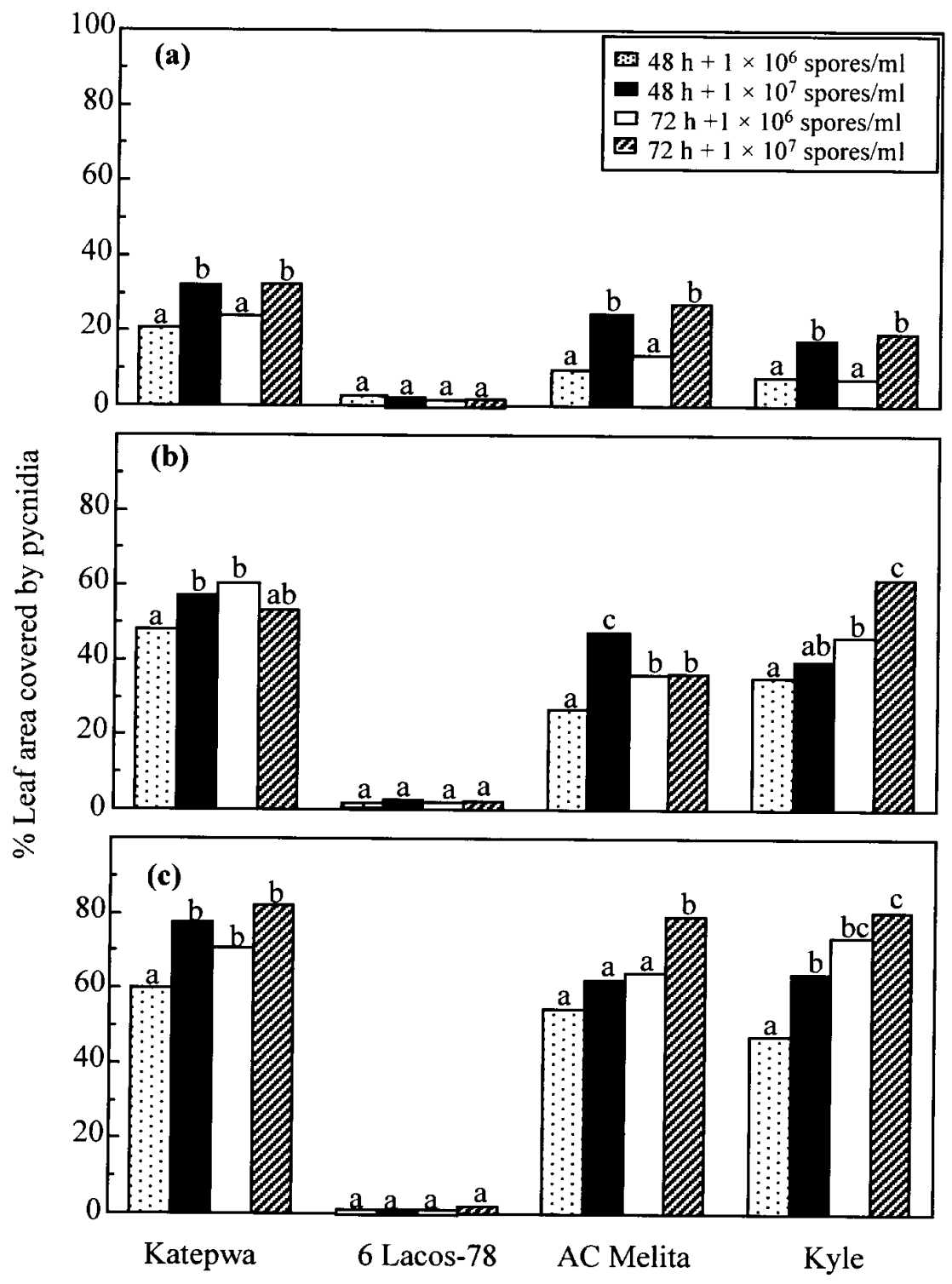

Cultivars

Fig. 4. Effect of inoculum concentration and duration of leaf wetness on development of Septoria tritici blotch on seedlings of bread wheats, Katepwa and 6 Lacos-78, and durum wheats AC Melita and Kyle, at three post-inoculation incubation temperatures: $\mathbf{A}, 15^{\circ} \mathrm{C}$ day $/ 11^{\circ} \mathrm{C}$ night; $\mathbf{B}, 18^{\circ} \mathrm{C}$ day $/ 15^{\circ} \mathrm{C}$ night; and $\mathbf{C}, 22^{\circ} \mathrm{C}$ day $/ 15^{\circ} \mathrm{C}$ night. Different letters associated with bars within genotypes are significantly different at $P<0.05$.

ness combination used in this study $(48 \mathrm{~h}+$ $1 \times 10^{6}$ spores $/ \mathrm{ml}$ ) was adequate to incite infection when seedlings were exposed to temperatures higher than $15^{\circ} \mathrm{C}$ day $/ 11^{\circ} \mathrm{C}$ night. The lower levels of infection on susceptible lines at $15^{\circ} \mathrm{C}$ day $/ 11^{\circ} \mathrm{C}$ night, despite high inoculum concentrations and longer duration of leaf wetness combination, shows the importance of temperature on the infection process and subsequent pycnidial development.

In this study we found that the reaction of the three cultivars widely grown in western Canada and 6 Lacos-78, a South American cultivar, responded differently to the three incubation temperatures, inoculum concentrations, and durations of leaf wetness. Cultivar 6 Lacos-78 maintained its resistance under all incubation temperatures, whereas the three susceptible cultivars had a moderately resistant reaction at $15^{\circ} \mathrm{C}$ day $/ 11^{\circ} \mathrm{C}$ and susceptible reactions at higher temperatures. Inoculation and exposure of wheat cultivars to various incubation temperatures, inoculum concentrations, and leaf-wetness durations revealed the importance of these factors in Septoria tritici blotch development. We also found that an inoculum concentration of $1 \times 10^{7}$ spores $/ \mathrm{ml}$, leaf wetness duration of $48 \mathrm{~h}$, and temperature of $18^{\circ} \mathrm{C}$ day $/ 15^{\circ} \mathrm{C}$ night or $22^{\circ} \mathrm{C}$ day $/ 15^{\circ} \mathrm{C}$ night were conditions required to obtain consistent infection to readily separate the susceptible and resistant cultivars in this study.

\section{ACKNOWLEDGMENTS}

This work was supported by grants from the Matching Investment Initiative and the WGRF Wheat Check-off. We are grateful to G. H. J. Kema for supplying Septoria tritici isolate 91014 used in this study. The technical assistance of $U$. Kromer was highly appreciated.

\section{LITERATURE CITED}

1. Brokenshire, T. 1975. The role of graminaceous species in the epidemiology of Septoria tritici on wheat. Plant Pathol. 39:376-390.

2. Chungu, C., Gilbert, J., and Townley-Smith, F. 1998. Grain yield and kernel weight reductions in spring wheat genotypes inoculated with Septoria tritici. (Abstr.) Can. J. Plant Pathol. 21:315

3. Eyal, Z., Scharen, A. L., Huffman, M. D., and Prescott, J. M. 1985. Global insights into virulence frequencies of Mycosphaerella graminicola. Phytopathology 75:1456-1462.

4. Eyal, Z., Scharen, A. L., Prescott, J. M, and Van Ginkel, M. 1987. The Septoria diseases of wheat: Concepts and methods of disease management. CIMMYT. Mexico, D.F.

5. Gilbert, J., Woods, S. M., and Tekauz, A. 1998. Relationship between environmental variables and the prevalence and isolation frequency of leaf-spotting pathogens in spring wheat. Can. J. Plant Pathol. 20:158-164.

6. Gough, F. J. and Lee T. S. 1985. Moisture effects on the discharge and survival of conidia of Septoria tritici. Phytopathology 75:180-182.

7. Hess, D. E., and Shaner G. 1987. Effect of moisture and temperature on development of Septoria tritici blotch in wheat. Phytopathology 77:215-219.

8. Hess, D. E., and Shaner G. 1987. Effect of moisture on Septoria tritici blotch develop- 
ment on wheat in the field. Phytopathology 77:220-226

9. Holmes. S. J. I., and Colhoun J. 1975. Strawborne inoculum of Septoria nodorum and $S$. tritici in relation to incidence of disease on wheat plants. Plant Pathol. 24:63-66.

10. King, J. E., Cook, R. J., and Melville, S. C. 1983. A review of Septoria diseases of wheat and barley. Ann. Appl. Biol 103:345-373.

11. Magboul, A. M., Geng, S., Gilchrist, D. G., and Jackson, L. F. 1992. Environmental influence on the infection of wheat by $M y$ cosphaerella graminicola. Phytopathology 82:1407-1413.

12. Potts, A. D. 1990. Expression and genetics of resistance to Septoria tritici in wheat. Ph.D. diss. Univ. of Saskatchewan.

13. Shaner, G. 1981. Effect of environment on fungal leaf blights of small grains. Ann. Rev. Phytopathol. 19:273-296.

14. Shaner, G., and Finney, R. E. 1976. Weather and epidemics of Septoria leaf blotch of wheat. Phytopathology 66:781-785.

15. Shaner, G., Finney, R. E., and Patterson, F. L. 1975. Expression and effectiveness of resistance in wheat to Septoria leaf blotch. Phytopathology 65:761-766.

16. Shaw, M. W. 1990. Effects of temperature, leaf wetness and cultivar on the latent period of Mycosphaerella graminicola on winter wheat. Plant Pathol. 39:255-268.

17. Shaw, M. W., and Royle, D. J. 1992. Airborne inoculum as a major source of Septoria tritici (Mycosphaerella graminicola) infections in winter wheat crops in the UK. Plant Pathol. 42:882-899.
18. Shearer, B. L. 1978. Inoculum density-host response relationships of spring wheat culti vars to infection by Septoria tritici. Neth. J. Plant Pathol. 84:1-12.

19. Shipton, W. A., Boyd, W. R. J., Rosielle, A A., and Shearer, B. L. 1971. The common Septoria diseases of wheat. Bot. Rev. 37:231262.

20. Van Ginkel, M., and Scharen A. L. 1988. Host-pathogen relationships of wheat and Septoria tritici. Phytopathology 78:762-766.

21. Zelikovitch, N., and Eyal, Z. 1991. Reduction in pycnidial coverage after inoculation of wheat with mixture of isolates of Septoria tritici. Plant Dis. 75:907-910.

22. Zadocks, J. C., Chang, T. T., and Konzak, C. F. 1974. A decimal code for the growth stage of cereals. Weeds Res. 14:415-421. 